\title{
QUANTITATIVE AND QUALITATIVE CHANGES IN MILK YIELD AND CHEESE-MAKING PROPERTIES OF MILK IN COWS VACCINATED AGAINST LUMPY SKIN DISEASE
}

\author{
Teodora Angelova ${ }^{*}$, Daniela Yordanova ${ }^{1}$, Jivko Krastanov $^{1}$, Daniela Miteva ${ }^{1}$, Georgi Kalaydhziev ${ }^{1}$, \\ Vladimir Karabashev ${ }^{1}$, Milena Mihaylova ${ }^{1}$, Plamen Marutsov $^{2}$, Nikolai Ivanov ${ }^{1}$ \\ ${ }^{1}$ Agricultural Institute, 6000 Stara Zagora, Bulgaria \\ ${ }^{2}$ Faculty of Veterinary Medicine, Trakia University - Stara Zagora, Bulgaria \\ teslacow@abv.bg
}

\begin{abstract}
A b s t r a c t: The aim of the present study was to analyze the changes in milk yield quantity and quality and cheese-making properties of milk in cows vaccinated against nodular dermatitis. The study was carried out with three groups of lactating cows (two experimental and one control) in the cattle farm of the Agricultural Institute, Stara Zagora. The rations of the experimental groups were supplemented with two different protein supplements. Milk yield (kg), milk protein and fat percentage, urea and milk coagulation traits (rennet coagulation time and curd firmness) were assessed on a weekly basis. Phenotypes were corrected with the following factors: group, lactation number, age in days to the test-day, days in lactation to the respective test-day of the respective lactation. After the vaccination, milk yield decreased statistically significantly along with deterioration of chemical composition of milk $(\mathrm{p}<0.001)$. Substantial deterioration of cheese-making properties of produced milk was found out, with prolonged rennet coagulation time and lower curd firmness.
\end{abstract}

Key words: milk coagulation property; lumpy skin disease

\section{КВАНТИТАТИВНИ И КВАЛИТАТИВНИ ПРОМЕНИ ВО ПРИНОСОТ НА МЛЕКО И ОСОБИНИТЕ ЗА ПРОИЗВОДСТВО НА СИРЕЊЕ ОД МЛЕКО НА КРАВИ ВАКЦИНИРАНИ ПРОТИВ БОЛЕСТА ЧВОРЕСТА КОЖА}

\begin{abstract}
А п с т р а к т: Целта на ова истражување беше да се утврдат промените на квантитетот и квалитетот во производството на млеко и на особините на млекото за производство на сирење кај крави вакцинирани од нодуларен дерматитис. Ова истражување беше поставено со три групи крави во лактација (две експериментални и една контролна) во говедарската фарма на Земјоделскиот институт во Стара Загора. Дажбите за експерименталните групи беа збогатени со два различни протеински додатоци. Производството на млеко (kg), процентот на протеини и масти во млекото, уреата и коагулацијата на млекото (времето на потсирување и цврстината на грушот) беа следени неделно. Кај фенотиповите беа следени следните фактори: група, број на лактации, возраст во денови на денот на експериментот, денови во лактација на денот на експериментот од испитуваната лактација. По вакцинацијата производството на млеко статистички се намали заедно со влошувањето на хемискиот состав на млекото $(\mathrm{p}<0.001)$. Беше забележано значително влошување на особините на произведеното млеко за производство на сирење, продолжено време на потсирување и помала цврстина на грушот.
\end{abstract}

Клучни зборови: особини на коагулацијаtа на млеко, болест чвореста кожа

\section{INTRODUCTION}

Infectious nodular dermatitis (Lumpy skin disease - LSD) is a viral disease affecting large ruminants - mainly cattle and buffaloes. All cattle breeds and age categories are susceptible, cultured breeds
(Holstein-Friesian) being more sensitive than aboriginal ones. Lumpy skin disease is mainly a vectorborne viral disease in bovines, enzootic in many African and Asian countries. It is first described in 1929 in Zambia (former North Rhodesia). Regardless of its extended region of spread, until 1980 LSD 
is territorially restricted to Africa and especially south of the equator. After 2000, nodular dermatitis is spread in Middle East countries with a large epizootic in Israel (2012) and Turkey and Northern Cyprus $(2013,2014)$. The morbidity rate varies from 5 to $45 \%$. Only half of affected cattle show clinical signs of disease characterized with development of cutaneous nodules with deep necrosis of all skin layers, subcutaneous tissue and underlying muscles. Pregnant animals could abort the foetuses in the fever stage. Although the major part of infected animals does not exhibit any clinical signs, they are capable to shed and spread the virus among the population. The death rate is under 10\% (Practical Manual 2015, BFSA).

In 2013, Coetzer and Tuppurainen report that probably, lumpy skin disease could spread to larger areas and pose a threat to cattle in Greece, Bulgaria, the Caucasus region, as well as Iran and Syria.

The disease is considered economically important in large ruminants entailing serious economic losses from reduced milk production, lack of appetite and weight loss, poor growth performance, abortions, infertility, damage of the skin, pneumonias, especially in animals with respiratory lesions (Tageldin et al., 2014; Zeynalova et al., 2016; Abdulqa et al., 2016; Tuppurainen, 2005; Tuppurainen and Oura, 2011).

The effect of vaccination on the productivity of animals has been conducted with cows reared in Ethiopia (Aylet et al., 2013). The authors concluded that in all 476 animals included in the study, milk yield decreased by $2-14 \mathrm{~kg}$ or by $5 \mathrm{~kg}$ daily on the average. A similar study in Oman with 3200 Holstein cows established that the production of milk from animals has declined by $40-65 \%$, and losses continued for several months (Somasundaram Mathan Kumar, 2011; Getachew et al., 2010).

The reduction of daily milk yield of cows reared in the Bani Kenanah region in Jordan ranged from 0 to $100 \%$, or $51.5 \%$ on the average (Abutarbush et al., 2015). It was shown that the disease continued to spread in the Middle East region posing a serious threat to the other part of Asia and Europe.

The World Organization for Animal Health (OIE) has included LSD in the list of notifiable diseases due to the substantial economic losses (OIE, 2010).

The aim of the present study was to analyze the effect of vaccination against nodular dermatitis on changes in milk yield quantity and quality and cheese-making properties of milk in cows fed different dietary protein supplements.

\section{MATERIAL AND METHODS}

A production experiment with three groups lactating cows ( 2 experimental and one control) was performed at the cattle farm of the Agricultural Institute - Stara Zagora. The animals were equalized and allotted in groups of 12. The experiment took place in the period 31.03.2016 - 28.06.2016. Cows were fed total mix ration with a different protein supplement for both experimental groups. On 28 April 2016, they were vaccinated against lumpy skin disease.

During the trial, the time course of the following milk productivity and milk coagulation traits was followed out: daily milk yield $(\mathrm{kg})$, milk fat and protein content $(\%)$; urea $(\mathrm{mg} / \mathrm{dl})$, rennet coagulation time (min); curd firmness (mm). Individual milk samples were collected at the time of morning milking, without adding preservative. The analysis of milk quality was done at the laboratory of the Agricultural Institute - Stara Zagora, on an ultrasonic milk analyzer Lactoscan. Coagulation ability of individual milk samples was evaluated at the laboratory of the Agricultural Institute - Stara Zagora through Computerized Renneting Metter - Polo Trade, Italy. Milk was analyzed within 3 hours after sampling. Urea content was analyzed by the method described by Angelov, Ibrishimov, Milashki (1999) on the basis of the urease method of Conway.

A mixed linear model was used for unbiased estimation of traits in a model, in which each testday was interpreted as separate observation:

- Vector of observation for the amount of milk (ml) at the respective test-day of each animal included in the analysis; milk fat and protein content; milk urea; rennet coagulation time, curd firmness.

- Vector of fixed effects - breed, group, number of lactation, age (days) to the test-day date, days I lactation at the respective test-day from the respective lactation.

$$
\begin{gathered}
Y_{i j k l m}=\text { Breed }_{i}+\text { Group }_{j}+\text { Pl }_{k}+\text { Testdim }_{l}+ \\
+ \text { Age }_{m}+e_{i j k l m}
\end{gathered}
$$

where:

$Y_{i j k l m}-m^{\text {th }}$ observation of the trait;

Breed $_{i}$ - fixed effect of the $i^{\text {th }}$ breed;

Group $_{j}$ - fixed effect of the $j^{\text {th }}$ farm;

$P L_{k}$ - fixed effect of the $k^{\text {th }}$ lactation; 
Testdim $_{l}$ - random regression effect of the $l^{\text {th }}$ lactation days to the respective test-day of the respective lactation;

Age $_{m}-$ effect of the $\mathrm{m}^{\text {th }}$ age of calving;

$e_{i j k l m}$ - random effects of unobserved factors.

The software products Excel, Systat 13 and Statistika were used for data analysis.

\section{RESULTS AND DISCUSSION}

Lumpy skin disease is a viral disease caused by a poxvirus, necessitating mandatory vaccination of all animals. At the time of vaccination, the animals are in stress because the procedure is very painful and results in reduction of daily milk yield. Total for the three groups, the vaccination-induced reduction in milk yield was the most pronounced in the control group (Figure 1).

The differences in daily milk yield before and after vaccination in control cows and the group sup- plemented with protein source 2 were very significant $(p<0.001)$ and a tendency for statistically significant differences was present between the group fed protein source $1(\mathrm{p}<0.05)$ (Table 1).

The highest milk fat content was observed in milk produced by control cows, associated with lower milk yield (Figure 2). After the vaccination milk fat decreased substantially in the group fed protein source 1 and insignificantly in the other two groups (Table 2).

After the vaccination, considerably lower milk protein content was demonstrated in all three groups of cows. The animals that received protein source 2 differed statistically significantly vs controls $-\mathrm{p}<$ 0.001 , while the level of significance between the group with protein source 1 and control group was $\mathrm{p}<0.01$ (Table 3). The supplementation of the diet of experimental groups with protein did not result in higher milk protein content. Probably, vaccination was associated with change in the metabolism of nutrients and the extent of their utilisation, especially with respect to dietary protein (Figure 3 ).

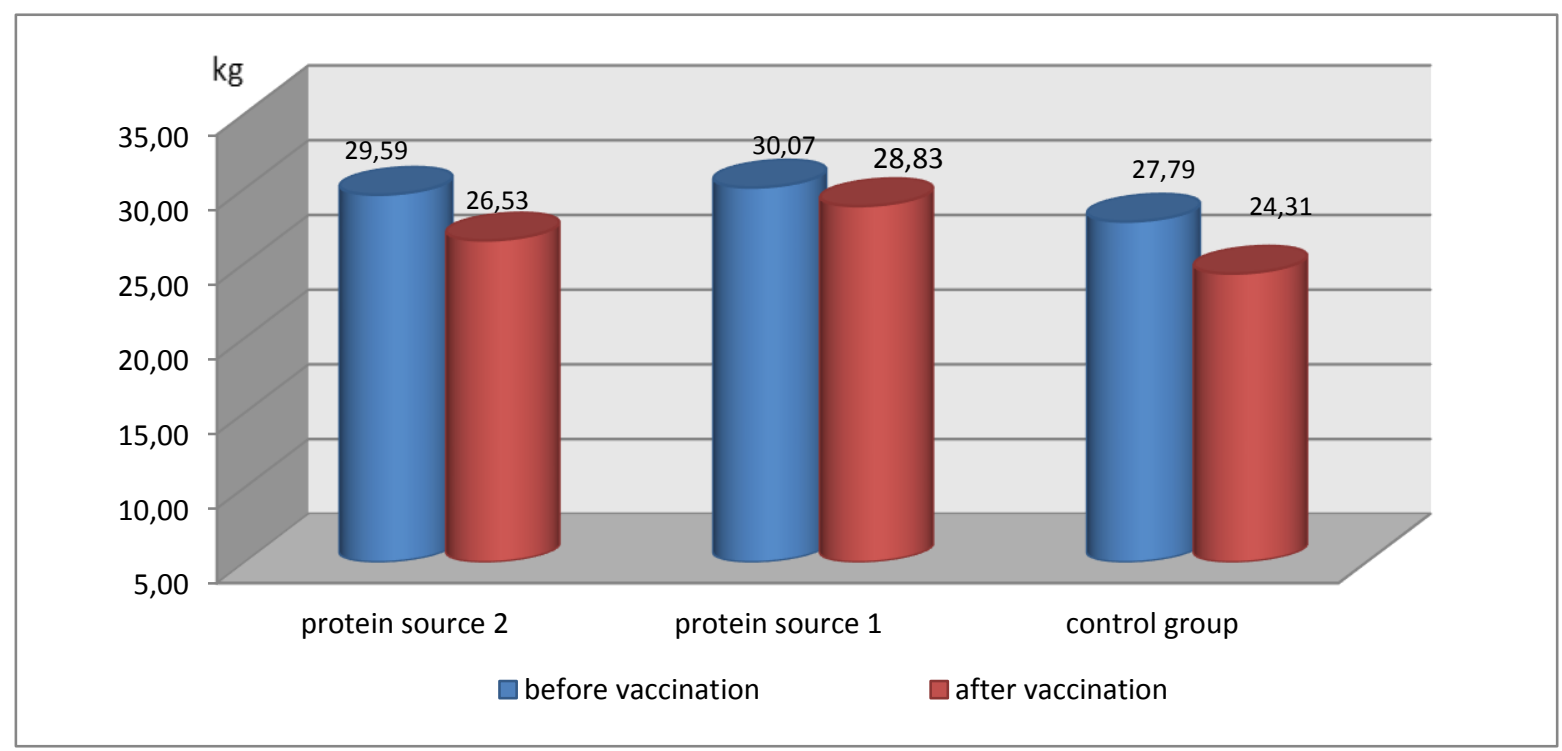

Fig. 1. Effect of vaccination against lumpy skin disease on daily milk yield

Table 1

Daily milk yield before and after vaccination

\begin{tabular}{lccccccccc}
\hline \hline \multirow{2}{*}{ Variable } & \multicolumn{2}{c}{ Group fed protein source 1 } & \multicolumn{2}{c}{ Group fed protein source 2 } & \multicolumn{2}{c}{ Control group } \\
& $\mathrm{N}$ & Mean & Mean difference & $\mathrm{N}$ & Mean & Mean difference & $\mathrm{N}$ & Mean & Mean difference \\
\hline Daily milk, kg before vaccination & 23 & 6.140 & & 24 & 3.179 & & 22 & 4.122 \\
Daily milk, kg after vaccination & 23 & 1.875 & $4.265^{*}$ & & 24 & -2.328 & $5.506^{* * *}$ & & $6.139^{* * * *}$ \\
\hline \hline
\end{tabular}

$*: \mathrm{p}<0.05, * * *: \mathrm{p}<0.001$ 


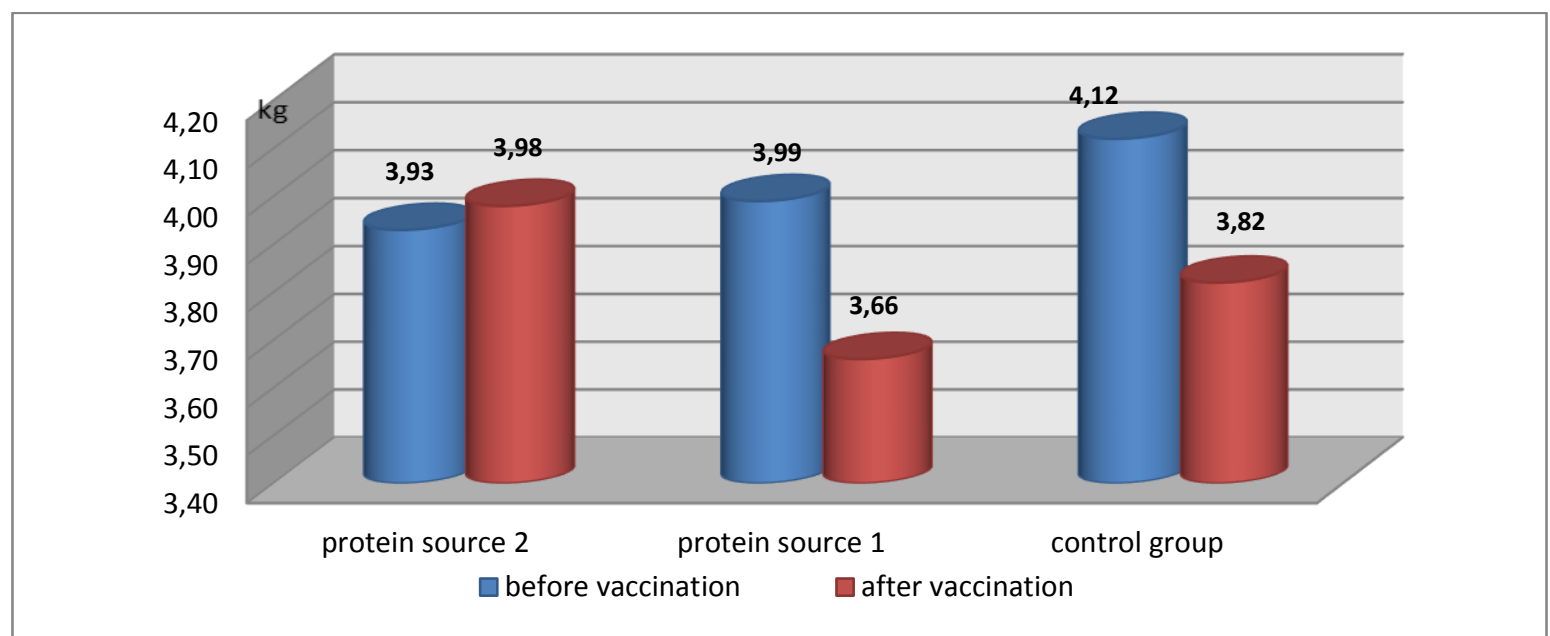

Fig. 2. Effect of vaccination against lumpy skin disease on milk fat content

Table 2

Milk fat content before and after the vaccination

\begin{tabular}{lccccccccc}
\hline \hline \multirow{2}{*}{ Variable } & \multicolumn{3}{c}{ Group fed protein source 1 } & \multicolumn{3}{c}{ Group fed protein source 2 } & \multicolumn{2}{c}{ Control group } \\
& $\mathrm{N}$ & Mean & Mean difference & $\mathrm{N}$ & Mean & Mean difference & $\mathrm{N}$ & Mean & Mean difference \\
\hline Fat, \% before vaccination & 23 & 1.841 & \multirow{2}{*}{$0.605^{*}$} & 24 & 1.601 & & 22 & 1.673 & 0.222 \\
Fat, \% after vaccination & 23 & 1.236 & & 24 & 1.342 & & 22 & 1.451 & \\
\hline \hline
\end{tabular}

$*: \mathrm{p}<0.05$,

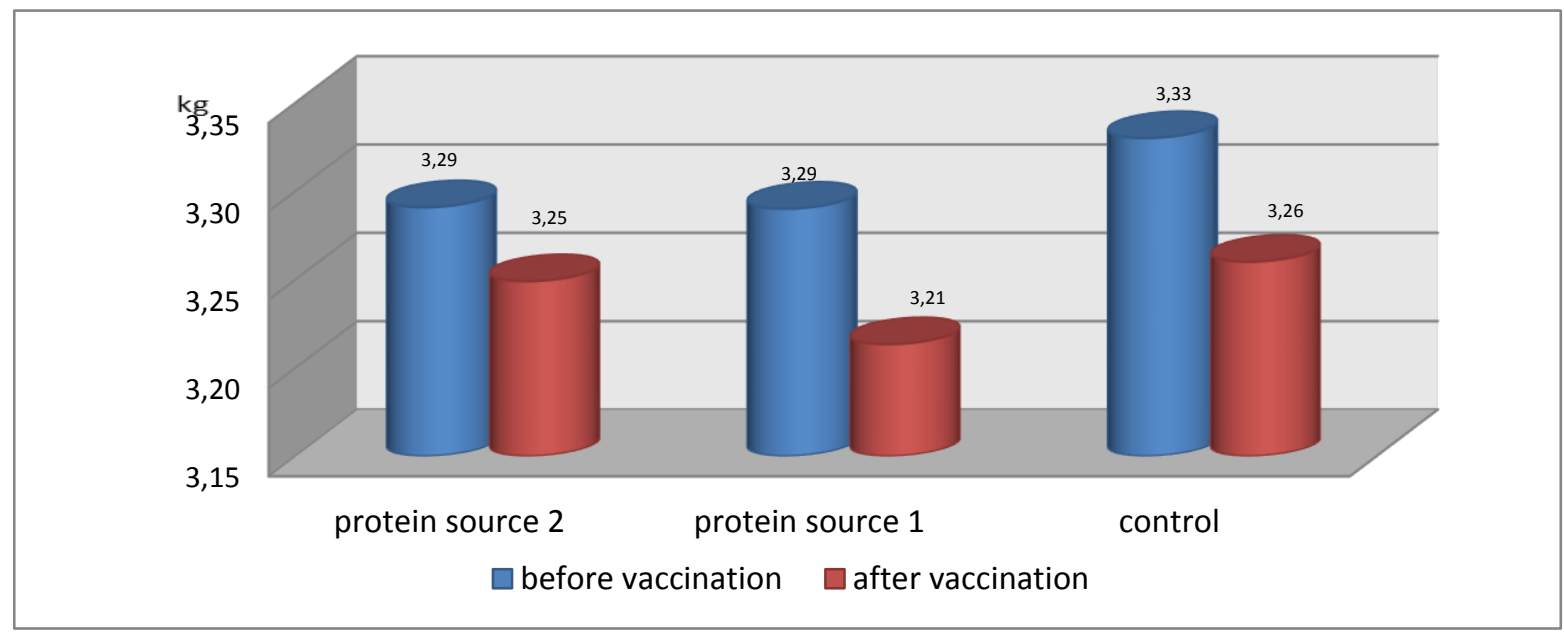

Fig. 3. Effect of vaccination against lumpy skin disease on milk protein content

Table 3

Milk protein content before and after the vaccination

\begin{tabular}{lcccccccccc}
\hline \multirow{2}{*}{ Variable } & \multicolumn{2}{c}{ Group fed protein source 1 } & \multicolumn{2}{c}{ Group fed protein source 2 } & \multicolumn{3}{c}{ Control group } \\
& $\mathrm{N}$ & Mean & Mean difference & $\mathrm{N}$ & Mean & Mean difference & $\mathrm{N}$ & Mean & Mean difference \\
\hline Protein, \% before vaccination & 23 & 1.956 & & 24 & 1.169 & & 22 & 1.797 & $0.605^{* * *}$ \\
Protein, \% after vaccination & 23 & 1.348 & $0.608^{* *}$ & 24 & 0.585 & & 22 & 1.192 & \\
\hline \hline
\end{tabular}

$*: \mathrm{p}<0.05, * *: \mathrm{p}<0.01, * * * \mathrm{p}<0.001$ 
The first trait characterizing milk coagulation properties - rennet coagulation time (RCT) exhibited prolonged values in the three groups (Table 4). Animals supplemented with dietary protein source 2 differed statistically significantly vs controls (Figure 4).

The second milk coagulation trait - curd firmness (A30) showed the firmest curd in the group fed protein source 2 as compared to controls (Table 5). Figure 5 shows that vaccination resulted in significant reduction of curd firmness in the three groups, with highly statistically significant effect in the group supplemented with protein source 2 , whereas the level of significance in the other two groups was $\mathrm{p}<0.05$.

Figure 6 and Table 6 proves that milk urea concentrations were higher in the group fed protein source 2 and control group vs cows fed protein source 1 . The increased values of this parameter after the vaccination were probably due to the stress from the procedure, and consequent alteration in protein metabolism. Under stress, gluconeogenesis is activated with resulting increased release of urea with the milk and urine of animals. The increased milk urea concentrations were most probably the cause for worsened coagulation properties of milk inferior rennet coagulation time and curd firmness.

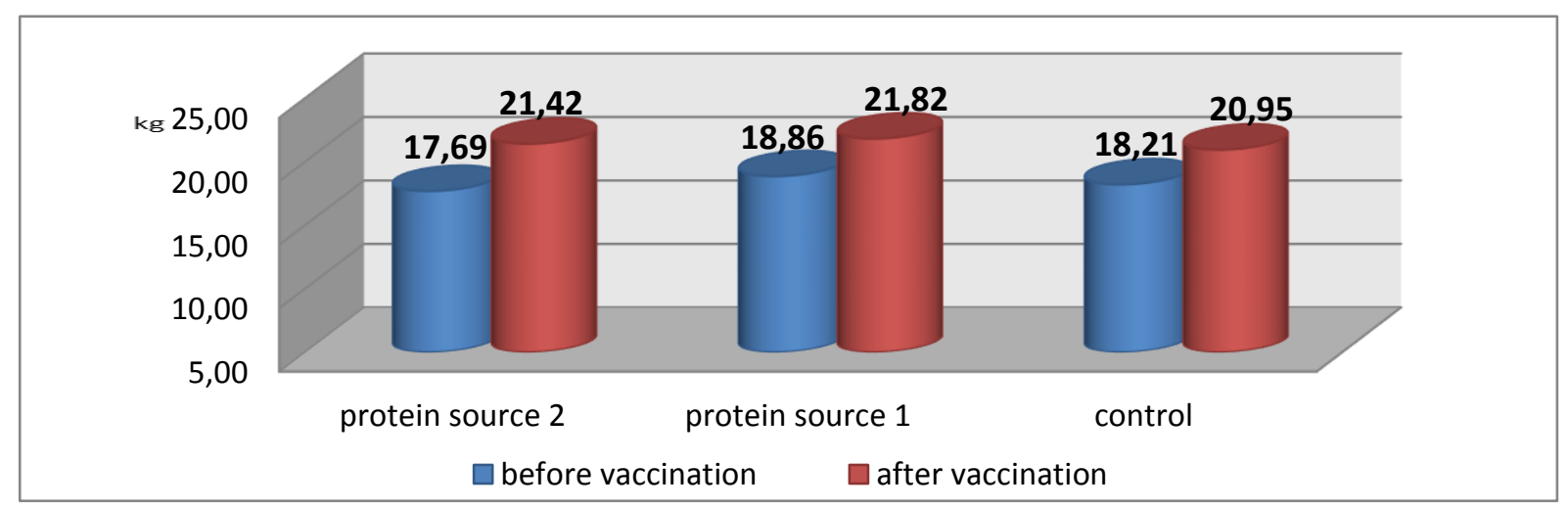

Fig. 4. Effect of vaccination against lumpy skin disease on rennet coagulation time of milk

Table 4

Rennet coagulation time (RCT) before and after the vaccination

\begin{tabular}{lccccccccc}
\hline \hline \multirow{2}{*}{ Variable } & \multicolumn{3}{c}{ Group fed protein source 1 } & \multicolumn{2}{c}{ Group fed protein source 2 } & \multicolumn{2}{c}{ Control group } \\
& $\mathrm{N}$ & Mean & Mean difference & $\mathrm{N}$ & Mean & Mean difference & $\mathrm{N}$ & Mean & Mean difference \\
\hline RCT, min before vaccination & 23 & 0.225 & \multirow{2}{*}{-3.613} & 24 & -2.343 & & 22 & -0.909 & $-3.652^{*}$ \\
RCT, min after vaccination & 23 & 3.838 & & 24 & 1.507 & $-3.850^{*}$ & 22 & 2.743 & \\
\hline \hline
\end{tabular}

$*: \mathrm{p}<0.05$

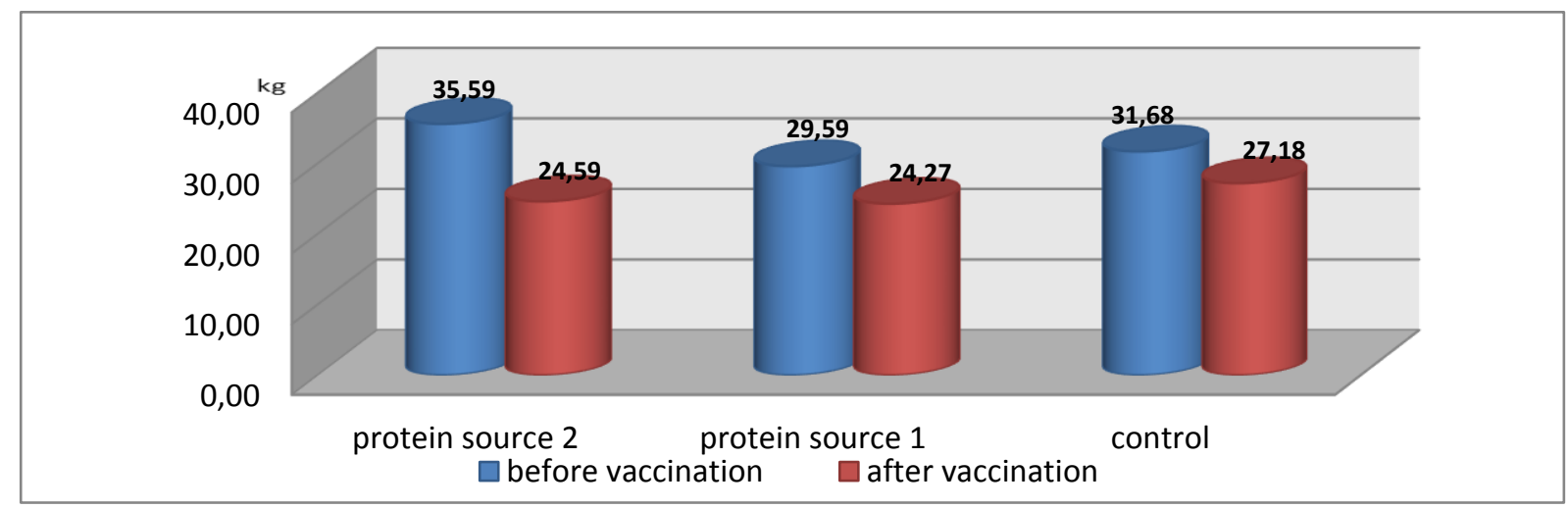

Fig/ 5. Effect of vaccination against lumpy skin disease on curd firmness 
Table 5

Curd firmness before and after the vaccination

\begin{tabular}{|c|c|c|c|c|c|c|c|c|c|}
\hline \multirow{2}{*}{ Variable } & \multicolumn{3}{|c|}{ Group fed protein source 1} & \multicolumn{3}{|c|}{ Group fed protein source 2} & \multicolumn{3}{|c|}{ Control group } \\
\hline & $\mathrm{N}$ & Mean & Mean difference & $\mathrm{N}$ & Mean & Mean difference & $\mathrm{N}$ & Mean & Mean difference \\
\hline Curd firmness, $\mathrm{mm}$ before vaccination & 23 & 6.507 & \multirow{2}{*}{$11.283^{*}$} & 24 & 7.714 & \multirow{2}{*}{$15.804 * * *$} & 22 & 6.388 & \multirow{2}{*}{$7.179^{*}$} \\
\hline Curd firmness, $\mathrm{mm}$ after vaccination & 23 & -4.776 & & 24 & -8.090 & & 22 & -0.792 & \\
\hline
\end{tabular}

*: $\mathrm{p}<0.05 ; * * *: \mathrm{p}<0.001$

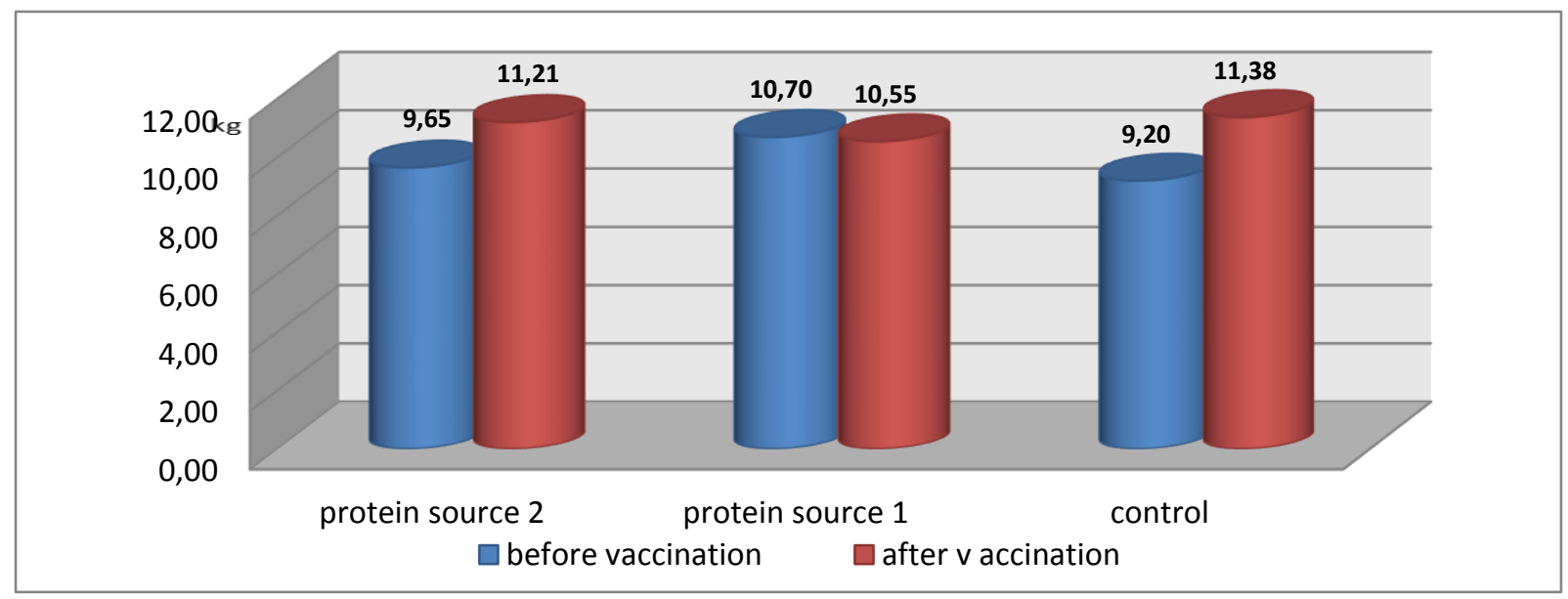

Fig. 6. Effect of vaccination against lumpy skin disease on milk urea content

Table 6

\section{Urea concentration before and after the vaccination}

\begin{tabular}{lcccccccccc} 
& \multicolumn{3}{c}{ Group fed protein source 1 } & \multicolumn{2}{c}{ Group fed protein source 2 } & \multicolumn{2}{c}{ Control group } \\
& $\mathrm{N}$ & Mean & Mean difference & $\mathrm{N}$ & Mean & Mean difference & $\mathrm{N}$ & Mean & Mean difference \\
\hline Urea before vaccination & 23 & -1.648 & & 24 & -3.111 & & 22 & -1.935 & $-5.276^{* * *}$ \\
Urea after vaccination & 23 & -0.199 & -1.499 & 24 & 2.008 & $-5.119^{* * *}$ & 22 & 3.342 & \\
\hline \hline
\end{tabular}

$* *: \mathrm{p}<0.01, * * *: \mathrm{p}<0.001$

The post-vaccination decline in milk yield of dairy cows is a negative sequel often reported by farmers and veterinarians. A transient reduction in milk yield and increased body temperature after vaccination were reported by Scott et al. (2001), Bosh et al. (1997), Musser et al. (1996) and Bergeron and Elsener (2001). The duration and magnitude of milk yield reduction depend on the type of vaccine (live or killed), included antigens, the type of adjuvant, production and stage of lactation of the animal, as well as from environmental factors. Scott et al. (2001) reported lower daily milk yield by up to $5 \mathrm{~kg}$ in cows with the highest milk production. In the same study, a mild fever for no more than 48 hours was detected. Similar post vaccination responses vanishing within 48 hours are not interpreted as adverse effects of vaccination. The vaccination against lumpy skin disease with live attenuated vaccine, as described by the manufacturer could produce the following side effects: local oedema with diameter of 10-20 mm; transient fever, reduced milk yield, a nodular dermatitis-like disease in up to $10 \%$ of vaccinated animals.

The involvement of the immune system and stress from vaccination together with pain, transient viraemia and fever provoked by the vaccinal strain are the main determinants associated with the health and productivity of vaccinated cows. 


\section{CONCLUSION}

After the vaccination, milk yield decreased statistically significantly along with deterioration of chemical composition of milk ( $p<0.001)$.

Substantial deterioration of cheese-making properties of produced milk was found out, with prolonged rennet coagulation time and lower curd firmness.

Milk urea concentrations were higher in the group fed protein source 2 and control group vs cows fed protein source 1 .

\section{REFERENCES}

[1] Abdulqa, H., Sulaiman Rahman, H., Othman Dyary, H., Hasan Othman, H. (2016): Lumpy skin disease, reproductive immunology: Open Access.

[2] Abutarbush, S. M., Ababneh, M. M., Al Zoubi, I. G., Al Sheyab, O. M., Al Zoubim, M. G., Alekish, M. O., Al Gharabat, R. J. (2015): Lumpy skin disease in Jordan: Disease emergence, clinical signs, Complications and preliminary-associated economic losses. Transboundary and Emerging Diseases. Vol. 62, Iss. 5, pp. 549-554.

[3] Ayelet, G., Abatec, Y., Sisayc, T., Nigussiec, H., Gelayea, E., Jemberiea, S., Asmare, K. (2013): Lumpy skin disease: Preliminary vaccine efficacy assessment and overview on outbreak impact in dairy cattle at Debre Zeit, central Ethiopia. Antiviral Research, 98, pp. 261-265.

[4] Bergeron, R., Elsener, J. (2008): Comparison of postvaccinal milk drop in dairy cattle vaccinated with one of two different commercial vaccines. Vet Ther. 9 (2), pp. $141-6$.

[5] Bosh, J. C., Frankena, K., Van Oirschot, J. T. (1997): Effect on milk production of vaccination with a bovine herpesvirus 1 gene-deleted vaccine. Vet Rec. 140 (8), pp. 196199.
[6] Coetzer, J .A. W. and Tuppurainen (2013): Lumpy skin disease. Adapted from: Coetzer, J. A. W. 2004, Lumpy skin disease, in: Infectious Diseases of Livestock, edited by Coetzer, J. A. W. \& Tustin, R. C., Cape Town: Oxford University Press Southern Africa, 2, 1268-1276.

[7] Gari, G., Waret-Szkuta, A., Grosbois, V., Jacquite, P. (2010): Risk factors associated with observed clinical lumpy skin disease in Ethiopia. Epidemiol. Infect. 138, 1657-1666. Cambridge University Press. DOI:10.1017/S0950268810000506

[8] Musser, K., Anderson, L. (1996): Effect of vaccination with an Escherichia coli bacterin-toxoid on milk production in dairy cattle. JAVMA, 209 (7), pp. 1291-1293.

[9] OIE (2010): Terrestrial Manual of Lumpy Skin Disease, Chapter 2.4.14. Version adopted by the World Assembly of Delegates of the OIE in May 2010, OIE, Paris.

[10] Scott H. M., Atkins G., Willows B., McGregor R. (2001): Effects of 2 commercially-available 9-way killed vaccines on milk production and rectal temperature in HolsteinFriesian dairy cows. Can Vet J., 42 (10), pp. 793-8.

[11] Somasundaram Mathan Kumar (2011): An outbreak of lumpy skin disease in a Holstein dairy herd in Oman: A clinical report. Asian Journal of Animal and Veterinary Advances, 6, 851-859.

[12] Tageldin, H., Wallace, D., Gerdes Putterill, J., Greyling, R., Phosiwa, M., Al Busaidy, R. M., Ismaaily, S. (2014): Lumpy skin disease of cattle: an emerging problem in the Sultanate of Oman. Trop Anim Health Prod., 46 (1), pp. 241-246.

[13] Tuppurainen, E. S. M. and Oura. C. A. L. (2011): Review: Lumpy Skin Disease: An Emerging Threat to Europe, the Middle East and Asia, Institute for Animal Health, Pirbright, Surrey, UK.

[14] Tuppurainen, S. M. (2005): Detection of the lumpy skin disease virus in samples of the experimentally infected cattle using different diagnostic techniques, MSc thesis.

[15] Zeynalova, S., Asadov, K., Guliyev, F., Vatani, M., Aliyev, V. (2016): Epizootology and molecular diagnosis of lumpy skin disease among livestock in Azerbaijan. Front Microbiol. 7, 1022. 